\section{DIGITAL COMMONS \\ @ UNIVERSITY OF SOUTH FLORIDA}

\section{ABO: Interactive Journal for Women in the Arts, 1640-1830}

Volume 4

Issue 2 Volume 4.2 (Fall 2014)

Article 4

2014

\title{
Review of Stephen Bending, Green Retreats: Women, Gardens and Eighteenth-Century Culture
}

Nicolle Jordan

University of Southern Mississippi, Nicolle.jordan@usm.edu

Follow this and additional works at: https://digitalcommons.usf.edu/abo

Part of the Feminist, Gender, and Sexuality Studies Commons, and the Literature in English, British Isles Commons

\section{Recommended Citation}

Jordan, Nicolle (2014) "Review of Stephen Bending, Green Retreats: Women, Gardens and EighteenthCentury Culture," ABO: Interactive Journal for Women in the Arts, 1640-1830: Vol.4: Iss.2, Article 4. http://dx.doi.org/10.5038/2157-7129.4.2.4

Available at: https://digitalcommons.usf.edu/abo/vol4/iss2/4

This Reviews is brought to you for free and open access by Digital Commons @ University of South Florida. It has been accepted for inclusion in ABO: Interactive Journal for Women in the Arts, 1640-1830 by an authorized administrator of Digital Commons @ University of South Florida. For more information, please contact digitalcommons@usf.edu. 
Review of Stephen Bending, Green Retreats: Women, Gardens and EighteenthCentury Culture

\author{
Abstract

\section{Keywords} \\ garden, landscape, women, British \\ Creative Commons License \\ (c) $($ ) $\ominus$
}

Review of Stephen Bending. Green Retreats: Women, Gardens and Eighteenth-Century Culture. New York: Cambridge UP, 2013. X +312 pp. Index. ISBN: 978-1-107-04002-1.

This work is licensed under a Creative Commons Attribution-No Derivative Works 3.0 License. 
Stephen Bending. Green Retreats: Women, Gardens and Eighteenth-Century Culture. New York: Cambridge UP, 2013. X +312 pp. Index. ISBN: 978-1-107-04002-1.

Reviewed by Nicolle Jordan University of Southern Mississippi

Stephen Bending's Green Retreats builds upon his previous work on eighteenth-century women and their gardens while also relying upon thorough knowledge of the cultural debates embedded in British garden historiography and landscape design. The introduction defines his focus on gardens of a certain size-landscape parks, not the flower or kitchen gardens with which women were so commonly associated, nor the pleasure gardens that entertained city-dwellers. Acknowledging that his focus confines him to women of considerable means, Bending emphasizes gender over class difference as the crucial one for his study. Thus focused, he sets out to challenge standard accounts of the era's landscape design, which feature the same handful of influential men (Charles Bridgeman, William Kent, Lancelot "Capability" Brown, and Humphry Repton), and follow a narrative of their successive "breakthroughs." Bending's case studies expose the hollowness of such one-sided stories. Running the gamut from the contrived simplicity of Elizabeth Montagu's self-fashioning as a "mere farmeress" to the more aggrieved banishment of Henrietta Knight (sister of Viscount Bolingbroke), these cases demonstrate how gardens - as imagined spaces as much as lived ones-encompass a vast range of women's experience, often involving piety and despair, ambition and resignation, in ways that mirror the contradictory expectations placed on women in a world that demands their virtue but expects their transgression.

Ample archival research has born rich fruit in this dense monograph. The first two chapters establish Bending's overarching concerns; the next four undertake the case studies (four extensive, one brief). One persistent concern is the ambiguous status of the garden as both private and public space; much as women might yearn-or be compelled-to embrace a private life, the larger cultural conversation treats gardens as a consummate expression of taste, and thus as a marker not only of status but also of moral worth. No matter how private one's experience of the garden might be, one is always aware of being judged by a broader community. Gardening is thus a way for women to engage with their culture and construct a public identity, paradoxically by shaping private space. Throughout, Bending plumbs intriguing dimensions of such contradictions, best encapsulated in the dual function of the garden as refuge and prison. The first case study, on the Bluestocking hostess Elizabeth Montagu, illustrates how pastoral tropes enabled her simultaneously to disavow and indulge in her fondness for luxury. Aware of the risks of being identified as a 'fine lady,' Montagu seized upon rural life-its solitude, productivity, and suitability for pious contemplation - as a way to purify her public profile, largely determined by her prominence as a salon hostess in London. Yet as Bending reveals in her letters (many unpublished), "[T] hat account of solitude persistently vacillates between pleasure and loss, tranquility and loneliness, friendship and its absence" (145). Bending uses Montagu's frequent and oft-repeated comments about her gardens and the landscape improvements she undertook at Sandleford Priory, with the aid of "Capability" Brown, to reveal how she uses virtuous retirement to counterbalance the negative associations accruing to her massive wealth. "The problem," he explains, "is that—as a product of wealth and a sign of luxury - the garden is as much a site of fashion as of meditation, as much an assertion of 
property as an occasion for piety" (170). Here Bending alludes to the class conflict encoded in Montagu's manipulation of her pastoral persona. Yet he occasionally comes across as an apologist for Montagu, whose devotion to charity provokes skepticism from some of her contemporaries as well as our own (James Woodhouse, the 'shoemaker poet' and recipient of her patronage being perhaps the most damning example). Indeed, the book's implicit sympathy for elite women who gardened risks alienating critics seeking analysis of a broader scope of women's experience (cf. William Christmas and Donna Landry). Yet Bending is aware of what some might consider a flaw in his design, and he mitigates it by tracking the precarious stature even of gentlewomen, whose elusive virtue always threatens to revoke what their birth has granted them. Moreover, the focus on elite women results, he explains, from the limitations of the historical record: "[W]e must move some way up the social scale if we are to find sustained accounts of women's gardening life" (242).

Montagu's heavy purse seems an easy burden to bear when compared to the challenges faced by the women who follow her in this study. Chapter Four, "Neighbors in Retreat," sets Lady Mary Coke alongside Lady Caroline Fox (later Baroness Holland). The two were neighbors on the outskirts of London, yet they lived in rural retirement for different reasons and consequently interpreted it in strikingly different ways. At Holland House, Lady Caroline involved herself in the landscape designs undertaken by her husband Henry Fox, an influential politician (and Paymaster of the Forces) who consulted William Kent and then "Capability" Brown for advice on estate improvements. The differences between Lord and Lady Holland's approach to Holland House illustrate the gendering of such undertakings. When Henry's political career faltered, he sought a more private retreat that was further removed from political intrusions than Holland House proved to be. Kingsgate, on the Isle of Thanet off the coast of Kent, suited both husband and wife. Yet, in a perfect illustration of how pastoral fancy remains entangled with that which it purports to reject, Henry protested his political losses (of the Paymaster position, and of stature under allegations of misusing state funds) by remodeling Kingsgate with gothic and classical structures that "reasserted his credentials as a patriot who held on to his country's ancient values and liberties" (185). These projects, rife with political maneuvering even in an arboreal context, left little room for Caroline, and her letters suggest Holland House remained her preferred retreat, temporary as it always was given regular stays in London and Kingsgate. In Caroline, unlike Montagu, Bending finds a woman less bent on constructing her self-image through proper conduct in her garden; instead, Caroline is much more candid about simply enjoying the fruits of her labor: "Holland House offered the pleasure of seeing her plants, the pleasure of peace, of quiet, and of course the pleasure of leaving behind her husband's insistent political world" (190).

In contrast to Lady Caroline, her neighbor Lady Mary Coke endured a lonely retirement rather than embracing it as her heart's desire. Both women knew scandal, Caroline having eloped with Henry, and Mary causing a rift between two powerful families when she resisted marriage to a notorious libertine, Viscount Coke, and then, after submitting to her family's will, sued for (but failed to win) a divorce. Scandal trailed her throughout life, and Bending explains that she "seems to have clung to it [...] as a badge of shame" (196), even after her husband's death and the public's amnesia meant their opprobrium subsided. Gardening offered Lady Mary sustained relief from what she experienced as abandonment by family and friends. Her move to the country estate of Notting Hill was precipitated by the death of the Duke of York, with whom she was intimate but who failed to satisfy her expectations of a marriage proposal. In letter-journals to her 
sisters (which nevertheless failed to win their sympathy), she charted her work in landscape design: creating views, constructing a mount and gravel walks, planting trees and shrubs, and so forth. With considerably less wealth at her disposal than Montagu or the Hollands, Lady Mary was more physically involved in her garden than they were, writing, "I worked hard all this Evening, tying up honeysuckles, sowing annuals, \& weeding" (191). Despite her pleasure in such work, Lady Mary's letters express enduring grief that no-one visits her; indeed, despite evidence that she received visitors regularly, she experienced Notting Hill as a place of isolation, which she interpreted as censorious rejection. Bending performs an impressive balancing act by exposing what appears to have been a rather trying personality while at the same time evoking admiration for the creative outlets through which she managed her affliction.

The fifth chapter features another woman who experienced rural retirement as punishment rather than paradise. Henrietta Knight, Lady Luxborough, was banished to Barrells Hall in Warwickshire when her husband intercepted what appeared to be love letters but may have been mere exercises in writing pastoral romance, exchanged with her friends Elizabeth Rowe, Lady Hertford, and the latter's son's tutor, John Dalton. As with the Hollands, Bending contrasts the retirement experiences of man and woman-here Viscount Bolingbroke and his sister Henrietta - in order to show the limitations of women in retirement, who could not avail themselves of the classical sources that ennobled and sanctified men's withdrawal from public life. Though she found estate management wearisome, Knight derived some pleasure in designing her gardens. In correspondence with her friend William Shenstone of the Leasowes, she "argu[es] for a domestic scale of design and expenditure," and by defying conventional associations of luxury and effeminacy, she "recuperates for women [...] the garden as a place of pleasure potentially untroubled by the insistent moralising of others" (227). Solitude, an abiding concern for all the women herein, is met with profound ambivalence by Knight, who resists the resignation counseled by Lady Hertford and instead faces debilitating depression when the landscape cannot assuage her loneliness. The stories of Lady Mary Coke and Lady Luxborough thus cast a shadow on rosy pictures of women basking in the splendor and ease of a landscape garden; they remind us that rural retirement could serve to exclude them from public life and even—in the case of Knight—separate them from their children.

In terms of critical orientation, Bending's book sits at the nexus of women's cultural history and landscape historiography. He is thus in good company with Elizabeth Bohls, Lisa L. Moore, and Jennifer Munroe (among others), who interpret early modern and Romantic women writers through the lens of their relationship to nature, whether cultivated or wild. It is perplexing, then, that Bending rarely engages with these or other critics whose interests overlap with his own. Typically he footnotes relevant sources, and directly engages with them only incidentally, so that one often lacks a sense of the larger critical stakes of his discussion. He is certainly not obliged to adopt prior approaches to the study of women and landscape; yet one wonders, for example, whether Bohls' articulation of the female aesthetic subject might amplify and enrich his exploration of the female imagination in engagement with retired life. Do traveling women (Bohls' interest) express a different perception of the landscape than do women confined (for the most part) at home? To be fair, among his subjects only Montagu qualifies as a "woman writer" in the typical sense, and Bending (like Moore) is more interested in a specific experiencegardening - shared by some women, for whom writing is not necessarily an avocation. Bending has identified a specific niche, and organizes his approach in order to interpret how various 
gentlewomen experienced gardening, and how these experiences diverged from those of gentlemen. What is missing in critical context is amply compensated for in Bending's voracious archival sleuthing, mostly undertaken at the Huntington Library and the British Library. Each chapter gathers momentum via lengthy quotations from the women's epistolary records, which often convey the drama surrounding their gardening projects. With twenty-five illustrations punctuating the five chapters (the brief sixth one serving as a coda), the book offers visual evidence of the milieu in which these women wrote; portraits, estate survey maps, paintings of the houses in question, and so on, add visual texture to the study.

By tracing the razor's edge that women tread when inhabiting narratives of rural retreat, Bending offers what is, to my mind, the most original thread of the book, delving deeply into tendencies previously noticed but not foregrounded. The garden emerges as perhaps a unique space in which for women to forge their identity, to confront limitations and to devise strategies for overcoming them. The brief final chapter further redresses the book's seemingly elitist slant by introducing a woman who echoes many concerns encountered heretofore, but who did not own the gardens she cultivated. Ellen Weeton, a governess in the early 1800s, labored under an indulgent master but an "odious" mistress who begrudged her employee's gardening pastimes even while appropriating them for her own leisure (244). Like Montagu, Holland, Coke, and Knight, Weeton also expresses a conflicted resignation to retirement, and "an urge to find in the garden a space which allows one to leave one's social position behind, and an equally strong sense that this is impossible" (245). Thus, Bending limns a kind of retroactive solidarity among women by noting commonalities in their gardening experience, regardless of social stature. Such a gesture calls attention to the need for further attention to whether women's experience of landscape serves to unite or separate them. Beyond this mandate, the most lasting impact of Green Retreats should be Bending's argument that women played a decisive role in the eighteenth-century cultural politics of landscape. I anticipate equally compelling work from scholars who assimilate his claims and continue to rewrite the overly masculine history of the landscape garden. 